\title{
COLD-PRESERVATION OF Lucilia sericata (DIPTERA: CALLIPHORIDAE) PUPAE AND ADULT PRODUCTS AS A NEW VENTURE TO ADULTS REARING
}

\author{
Hamzeh Alipour ${ }^{1,2}$, Marziae Shahriari-Namadi ${ }^{1}$, Abbasali Raz ${ }^{3}$, \\ Mohammad D. Moemenbellah-Fard ${ }^{1}$
}

\begin{abstract}
${ }^{1}$ Research Center for Health Sciences, Institute of Health, Shiraz University of Medical Sciences, Shiraz, Iran.
${ }^{2}$ Department of Medical Entomology, School of Health, Research Center for Health Sciences, Shiraz University of Medical Sciences, Shiraz, Iran

${ }^{3}$ Malaria and Vector Research Group, Biotechnology Research Center, Pasteur Institute of Iran, Tehran, Iran.
\end{abstract}

Received - February 09, 2018; Revision - April 21, 2018; Accepted - June 13, 2018

Available Online - June 20, 2018

DOI: http://dx.doi.org/10.18006/2018.6(3).544.549

\section{KEYWORDS \\ Cold-preservation \\ Lucilia sericata \\ Pupae}

Mass rearing

\begin{abstract}
Rearing insect colonies in insectarium is often encountered with some problems. Cold-preservation can serve as an alternate option and can save large amount of insects without time-lapse, this method is also found valuable and cost-effective. In present study Lucilia sericata adults were used for cold preservation. One hundred twenty (120) L. sericata pupae were used in this study, these insects were divided in three groups of forty member, and each group was stored in $50 \mathrm{ml}$ tubes containing sawdust and kept at $4^{\circ} \mathrm{C}$ for $3,6 \& 12$ months. After the completion of required exposure time $(3,6$ and 12 months), pupae were taken out from $4^{\circ} \mathrm{C}$ and placed under standard maggotarium conditions on sawdust in $40 \times 40 \mathrm{~cm}$ cages. This was followed by the counting adult number, result of study revealed that after three months, $28(70 \%)$ pupae were transformed into adults. While in case of 6 and 12 months this transformation number was $20(50 \%)$ and $8(20 \%)$ pupae respectively. From the result of study it can be concluded that this method is cost effective and time saving and $L$. sericata can be reared when ever required. This method opens new horizons for mass rearing of L. sericata for laboratory, research and business requirements
\end{abstract}

* Corresponding author

E-mail: m.shahriarinamadi@yahoo.com (MarziaeShahriari-Namadi)

Peer review under responsibility of Journal of Experimental Biology and Agricultural Sciences.

Production and Hosting by Horizon Publisher India [HPI] (http://www.horizonpublisherindia.in/).

All rights reserved.
All the article published by Journal of Experimental Biology and Agricultural Sciences is licensed under a Creative Commons Attribution-NonCommercial 4.0 International License Based on a work at www.jebas.org.

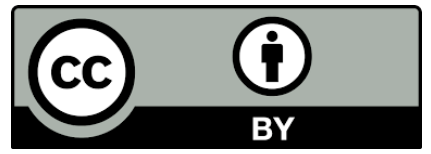




\section{Introduction}

Rearing of insect colonies in insectaries is faced with various problems such as colony breakdown, diseases, genetic drift, high labor and material costs and finally time-consuming (Leopold et al., 2001; Augustinos et al., 2016). Choices to continuous culture include the various stages of insect life cycle which undergo diapauses (Bourdais et al., 2012; Lee, 2012; Rinehart et al., 2013; Rajamohan et al., 2014). Cryopreservation or cold preservation are the methods which can maintain insects for along time in laboratory application and mass production when needed (Leopold et al., 2001). These techniques were successfully established in many insects species including embryo of Lucilia sericata and Bombyx mori but most cold storage procedures still need experimental verification (Rajamohan et al., 2014). Accordingly, degree of maintenance, sub-optimized conditions and reliable viability can be expected for only a few months of storage (Rajamohan et al. 2014). Longer periods of storage can affect the viability of insects, so it needs specific technique which can increase the survival of insect without any effecton a particular stage.

Longer periods of storage can be achieved through cryopreservation, although till date only six dipteran and two lepidopteran species have been successfully cryopreserved (Rajamohan et al., 2013; Augustinos et al., 2016). Insect ecophysiological features played important role in tolerating cold weather or cold tolerance, this can be used to maintain insect under cold-preservation. With the start of the cold season, the insect save extra energy to overcome winter. During cold, several biochemical changes such as change in total glucose, lipid, protein, and glycogen levels occurred in the insect body, which help these to survive under cold conditions. Insect capacity to tolerate low temperatures is referred as cold hardiness or cold tolerance (Lee, 1991; Santacruz et al., 2017). During cryopreservation, insects may face chilling injury, in this ice crystal forms inside the insect's body which lead to mechanical and osmotic stress (Sheikh et al., 2017). Cold shock damage is caused by brief exposure to below zero degrees (Chidawanyika et al., 2017; Saeidi et al., 2017). Freezing resistant insects are not vulnerable to the formation of ice crystals in their tissues because they contain proteins or peptides that protect them against extracellular freezing (Horwath \& Duman, 1983). However, in many species that show this physiological compatibility, survival depends on the temperature and the length of time spent in the frozen state. Also, most insects do not tolerate freezing (Salt, 1961).

The blow fly Lucilia sericata (Meigen 1826) (Diptera: Calliphoridae)(Beverley, 2012) is a fly with medicinal importance, it is also used in forensic medicine and agriculture (Tomberlin et al., 2017; Moemenbellah-Fard et al., 2018). From ancient time, L. sericata larvae have been reportedly applied to treat necrotic, infected and non-heal injuries, such as bedsore, burn and diabetic foot ulcers (Sherman \& Shimoda, 2004; Akbarzadeh et al., 2012). In medicine, larvae of $L$. sericata are used to treat wounds or applied in maggot debridement technology (Mirabzadeh et al., 2017). The larvae of L sericata secrete antibacterial peptide, proteases and growth factors in wound which affect the wound healing process (Alipour et al., 2017a). Further, these larvae feed on necrotic tissues of wound and change the $\mathrm{pH}$ of wound from acid to alkaline which leads to stimulation of the repair process. Therefore, due to the risk of damage to vital organs, risk of infection in surgical operations, speed of treatment, recovery in patients and the limited use of antibiotics, maggot therapy is recommended as a selective therapeutic approach (Rafinejad et al., 2014; Alipour et al., 2016; Hajimohammad et al., 2017)

In general, the use of larvae on a wound is the last option of defense and it is usually used when a patient has undergone antibiotic and surgical treatment and these two are completely unsuccessful (Rafinejad et al., 2014; Naafs, 2017). In forensic medicine, it is an important marker species used in the survey of the time since death that named post mortem interval (PMI) (Zajac et al., 2018). These flies are very important insects in criminal studies because a part has been created in forensic medicine (Bajerlein et al., 2018).

Larvae are generally colored and legless, have a sharp, upright tip, and are equipped with respiratory tract, which is one of the reasons for inter-species diagnosis (Amendt, 2004; Moemenbellah-Fard et al., 2018). By considering its medicinal, forensic and agricultural importance, the expansion of coldpreservation methods for the long-term storage is very significant under laboratory conditions (Sheikh et al., 2017). Present study has been undertaken to estimate the important factors which determined the cryopreservation of $L$. sericata. Further, potential roles that pupae play under cold conditions are also studied in present study and listed in Tables $1 \& 2$.

\section{Materials and methods}

\subsection{Rearing of Lucilia sericata}

The $L$. sericata colony used in this study was established on flies that were collected from field of Shiraz city of Fars province. The insects used in this study were the Old World Screw worm and therapeutic myiasis agents used in treatment of necrotic wounds (Alipour et al., 2017b). Adults were exposed to a 12h light/dark cycle, at a relative humidity of $40-50 \%$, and temperature range at $18-25^{\circ} \mathrm{C}$ under controlled conditions. The larvae were fed on ground chicken liver. Accurate species identification was confirmed by using morphological (Akbarzadeh et al., 2015) and 
Table 1 Viable and non-viable pupae of Lucilia sericata after three periods of time under cold-preservation

\begin{tabular}{|c|c|c|c|c|}
\hline Status & $\begin{array}{c}\text { First period } \\
3 \text { months storage }\end{array}$ & $\begin{array}{l}\text { Second period } \\
6 \text { months storage }\end{array}$ & $\begin{array}{c}\text { Third period } \\
12 \text { months storage }\end{array}$ & $\begin{array}{l}\text { Statistical analysis based on the } \\
\text { time of storage in } 4^{\circ} \mathrm{C}\end{array}$ \\
\hline viable & $28(70 \%)$ & $20(50 \%)$ & $8(20 \%)$ & \multirow{2}{*}{$P<0.05$} \\
\hline Non-viable & $12(30 \%)$ & $20(50 \%)$ & $32(80 \%)$ & \\
\hline
\end{tabular}

Table 2 Comparison of three groups of $L$. sericata pupae after three periods of time under cold-preservation

\begin{tabular}{|c|c|c|c|c|c|c|}
\hline \multirow[t]{2}{*}{ Groups } & \multirow{2}{*}{$\begin{array}{c}\text { Number of pupae } \\
\text { per group }\end{array}$} & \multirow[t]{2}{*}{$14^{\circ} \mathrm{C}$ Storage period } & \multirow{2}{*}{$\begin{array}{l}\text { Time of Release in } \\
\text { sectary conditions }\end{array}$} & \multicolumn{2}{|c|}{ Viable pupae } & \multirow{2}{*}{$\begin{array}{l}\text { Statistical analysis } \\
\text { between all groups }\end{array}$} \\
\hline & & & & Number & Percentage & \\
\hline \multirow{3}{*}{ Groups 1} & \multirow{3}{*}{40} & \multirow{3}{*}{3 Month } & After 48 hour & 8 & 20 & \multirow{9}{*}{$P<0.05$} \\
\hline & & & After 96 hour & 14 & 35 & \\
\hline & & & After 125 hour & 6 & 15 & \\
\hline \multirow{3}{*}{ Groups 2} & \multirow{3}{*}{40} & \multirow{3}{*}{6 Month } & After 48 hour & 6 & 15 & \\
\hline & & & After 96 hour & 11 & 27.5 & \\
\hline & & & After 125 hour & 3 & 7.5 & \\
\hline \multirow{3}{*}{ Groups 3} & \multirow{3}{*}{40} & \multirow{3}{*}{12 Month } & After 48 hour & 2 & 5 & \\
\hline & & & After 96 hour & 5 & 12.5 & \\
\hline & & & After 125 hour & 1 & 2.5 & \\
\hline
\end{tabular}

molecular tools (Tourle et al., 2009). Experiments were performed on the pupae of $L$. sericata fly from a colony that had been reared in Shiraz School of Health insectarium, Shiraz University of Medical Sciences (SUMS).

\subsection{Long-Term Cold-preservation}

One hundred twenty (120) L. sericata pupae were divided in three groups (40 in each group) and were stored at $4^{\circ} \mathrm{C}$ on 25 June 2016 and retrieved on 25 June 2017. The pupae were transferred to a $50 \mathrm{ml}$ falcon tube and were placed in a refrigerator at $4^{\circ} \mathrm{C}$. Hereafter, at the interval of 3, 6 and 12 month, 40 pupae were taken out from the refrigerator and placed under standard maggotarium conditions on sawdust in a $40 \times 40 \mathrm{~cm}$ cage.

\subsection{Pupae viability and Data analysis}

The procedure described above was used to revive the pupae, and the viability percentages were recorded. The percentages of pupae viability were evaluated based on the number of adults alive. Furthermore, statistical analysis was done by one-way ANOVA method and chi-square test in SPSS V.21 program was applied to compare the groups.

\section{Results}

First group of pupae which were taken out from the refrigerator (from $4^{\circ} \mathrm{C}$ ) after 3 months, out of 40 extracted pupae only 28 $(70 \%)$ of them were developed in to adults. While in case of second group (after 6 months) only $20(50 \%)$ and in third group (after 12 months) only 8 (20\%) of them were transformed in to the adults (Table1). Result of study revealed that with the increasing storage time at $4^{\circ} \mathrm{C}$ viability of pupae were decreased and this difference between viability and time of storage at cold conditions are significantly different $(P<0.05)$.

The first group that were stored at $4{ }^{\circ} \mathrm{C}$ for 3 months, the pupae were placed in mentioned cages in the maggotarium and after 48 hours 8 pupae were matured, while after 96 hours 14 (35\%) and after 125 hours 6 pupae were matured from 40 pupae. In second groups that were stored at $4^{\circ} \mathrm{C}$ for 6 months, after 48 hours, 6 pupae were matured while in case of 96 and 125 hours 11 and 3 pupae were matured respectively from 40 pupae. In third group that were stored at $4{ }^{\circ} \mathrm{C}$ for 12 months, after 48 hours, 2 pupae were matured, after 96 hours 5 pupae and after 125 hours 1 pupae was matured from 40 pupae (2.5\%) This study showed a significant difference between three groups $(\mathrm{P}<0.05)$ (Table 2$)$. 


\section{Discussion}

In this study viability of $L$. sericata pupae was assessed after storage at $4^{\circ} \mathrm{C}$ for 1 year. Survival was influenced by the lengthtime of the storage period. Studies have shown that insects have cold tolerance due to physiological and ecological adaptations (Overgaard \& MacMillan, 2017; Sheikh et al., 2017). So far, many studies have been carried out on the storage of eggs in freezing conditions and nitrogen tanks (Rajamohan et al., 2014), but effect of cold storage on insect pupae, especially on the fly pupae of $L$. sericata, has not been studied yet. This study revealed that adult flies of $L$. sericata can be obtained by storing the pupae at $4^{\circ} \mathrm{C}$ for one year without continuous rearing under maggotarium conditions. Therefore, there is no need to continuous rearing and care of this insect in maggotarium for molecular and morphological tests. This method can help researchers to mass rear without spending extra time and costs. In addition, coldpreservation method can help maggot therapy clinics in treatment of burns or diabetic wound (Saleh et al., 2014).

Cold acclimation of the green bottle blowfly pupae, L.sericata, could be manipulated to implement wound debridement therapy in a tropical region where many infectious diseases also prevail (Azizi et al., 2012; Farhadpour et al., 2016; Neghab et al.,2006). In this study, first time cold preservation of 120 L. sericata pupae was carried out under laboratory conditions. Wang preserved using cryo-preservation method in house fly which later led to development of a protocol for screw worms (Wang et al., 2000). The results of this research has many common features with previous studies on insect species such as $M$. domestica, $C$. hominivorax, Ceratitis capitata, Wiedemann and Anastrepha ludens (Leopold, 2007; Handler et al., 2009). This protocol was refined and used for preserving 12 screwworm strains, about 25000 embryos (Leopold et al., 2001; Suszkiw, 2005). We deduce that the cold-preservation protocol can be prosperous altered to the rearing of $L$. sericata in laboratory. From the result of study, it can be concluded that cold-preservation method reported in present study will benefit the current and upcoming users of this fly for research in medical entomology field, forensic entomology and larva therapy in medicine to treatment of wound healing by reducing the costs connected with mass product fly in laboratory condition. Eventually, it was expected that the development of this protocol for another insect species will increase its approval as an important tool for those who work on rearing insects.

\section{Acknowledgements}

This work was supported by the Research Fund of the National Institute for Medicinal Research Development (NIMAD) project numbers 957300 .

\section{Conflict of interest}

All the authors declare that there is no conflict of interest.

\section{References}

Akbarzadeh K, Rafinejad J, Alipour H, Biglarian A (2012) Human Myiasis in Fars Province, Iran. The Southeast Asian Journal of Tropical Medicine and Public Health 43: 1205-11

Akbarzadeh K, Wallman JF, Sulakova H, Szpila K (2015) Species identification of Middle Eastern blowflies (Diptera: Calliphoridae) of forensic importance. Parasitology Research 114: 1463-1472

Alipour H, Raz A, Dinparast Djadid N, Zakeri S (2017b) Lucilia sericata collagenase, US Patent App.15/410,697,2017 Available on https://patents.google.com/patent/US20170267988A1/en access on 25th February, 2018.

Alipour H, Raz A, Dinparast Djadid N, Zakeri S (2017a) Molecular characterization of matrix metalloproteinase-1 (MMP1) in Lucilia sericata larvae for potential therapeutic applications. Electronic Journal of Biotechnology 29: 47-56.

Alipour H, Raz A, Dinparast Djadid N, Zakeri S (2016) Therapeutic applications of collagenase (metalloproteases): Areview. Asian Pacific Journal of Tropical Biomedicine 6: 975-981.

Amendt J, Krettek R, Zehner R. Naturwissenschaften (2004) Forensic entomology. Naturwissenschaften 91:51-65.

Augustinos AA, Rajamohan A, Kyritsis GA, Zacharopoulou A, Haq Iu, Targovska A, Caceres C, Bourtzis K, Abd-Alla AMM (2016) Cryopreservation of Embryos of the Mediterranean Fruit Fly Ceratitis capitata Vienna 8 Genetic Sexing Strain. PloS one 11: $\mathrm{e} 0160232$.

Azizi K, Abedi F, Moemenbellah-Fard MD (2012) Identification and frequency distribution of Leishmania (L.) major infections in sand flies from a new endemic ZCL focus in southeast Iran. Parasitology Research 111(4): 1821-1826.

Bajerlein A, Taberski D, Matuszewski S (2018) Estimation of postmortem interval (PMI) based on empty puparia of Phormia regina (Meigen) (Diptera: Calliphoridae) and third larval stage of Necrodes littoralis (L.) (Coleoptera: Silphidae) - Advantages of using different PMI indicators. Journal of Forensic and Legal Medicine 55: 95-98

Beverley AH (2012) Morphological characters to identify adult Lucilia sericata (Meigen, 1826) and $L$. cuprina (Wiedemann, 1830) (Diptera: Calliphoridae). New Zealand Journal of Zoology 18: 413-420. DOI: 10.1080/03014223.1991.10422847 
Bourdais D, Vernon P, Krespi L, Baaren JV (2012) Behavioural consequences of cold exposure on males and females of Aphidius rhopalosiphi De Stephani Perez (Hymenoptera: Braconidae). BioControl 57: 349-360

Chidawanyika F, Nyamukondiwa C, Strathie L, Fischer K (2017) Effects of thermal regimes, starvation and age on heat tolerance of the parthenium beetle Zygogramma bicolorata (Coleoptera: Chrysomelidae) following dynamic and static protocols. PloS one 12: $\mathrm{e} 0169371$

Farhadpour F, Telmadarraiy Z, Chinikar S, Akbarzadeh K, Moemenbellah-Fard MD (2016)Molecular detection of CrimeanCongo haemorrhagic fever virus in ticks collected from infested livestock populations in a New Endemic Area, South of Iran. Tropical Medicine and International Health 21(3): 340-347.

Hajimohammad K, Esmaili R, Rahimi Z (2017) Maggot Debridement Therapy for Diabetic Foot Ulcer: A Case Report." Journal of Critical Care Nursing 10(3): doi: 10.5812/ccn.9836.

Handler A, Allen M, Skoda R (2009) Development and utilization of transgenic New World screwworm, Cochliomyia hominivorax. Medical and veterinary entomology 23: 98-105

Horwath KL, Duman JG (1983) Induction of antifreeze protein production by juvenile hormone in larvae of the beetle, Dendroides canadensis. Journal of Comparative Physiology 151: 233-240

Tomberlin JK, Crippen TL, Tarone AM, Chaudhury MF, Singh B, Cammack JA, Meisel R (2017) A review of bacterial interactions with blow flies (Diptera: Calliphoridae) of medical, veterinary, and forensic importance. Annals of the Entomological Society of America 110:19-36., https://doi.org/10.1093/aesa/saw086

Lee RE (1991) Principles of Insect Low Temperature Tolerance In: Lee RE, Denlinger DL (Eds.) Insects at Low Temperature. Springer, Boston, MA. DOI https://doi.org/10.1007/978-1-47570190-6_2

Lee RE, Denlinger D (2012) Principles of Insect low temperature tolerance. In: Lee RL (ED) Insects at low temperature. Springer Science \& Business Media. ISBN 978-1-4757-0192-0. DOI: 10.1007/978-1-4757-0190-6.

Leopold R, Wang W, Berkebile DR, Freeman TP (2001) Cryopreservation of embryos of the New World screwworm Cochliomyia hominivorax (Diptera: Calliphoridae). Annals of the Entomological Society of America 94: 695-701

Leopold RA (2007) Colony Maintenance and Mass-Rearing: Using Cold Storage Technology for Extending the Shelf-Life of
Insects. In: Vreysen MJB, Robinson AS, Hendrichs J (Eds) AreaWide Control of Insect Pests. Springer, Dordrecht

Mirabzadeh A, Ladani M, Imani B, Rosen SAB, Sherman RA (2017) Maggot therapy for wound care in Iran: a case series of the first 28 patients. Journal of wound care 26: 137-143

Moemenbellah-Fard MD, Keshavarzi D, Fereidooni M, Soltani A (2018) First survey of forensically important insects from human corpses in Shiraz, Iran. Journal of Forensic and Legal Medicine 54: 62-68.

Naafs MAB (2017) The Maggots: Professional Wound Cleaners. Available on https://infectioncontrol.tips/2017/10/31/maggotsprofessional-wound-cleaners/ access on $25^{\text {th }}$ February, 2018.

Neghab M, Moosavi S, Moemenbellah-Fard MD (2006) Prevalence of intestinal parasitic infections among catering staff of students' canteens at Shiraz, Southern Iran. Pakistan Journal of Biological Sciences 9(14): 2699-2703.

Overgaard J, MacMillan HA (2017) The integrative physiology of insect chill tolerance. Annual Review of Physiology 79: 187-208

Rafinejad J, Akbarzadeh K, Rassi Y, Nozari J, Sedaghat MM, Hosseini M, Alipour H, Ranjbar A, Zeinali D (2014)Traumatic myiasis agents in Iran with introducing of new dominant species, Wohlfahrtia magnifica (Diptera: Sarcophagidae) Asian Pacific Journal of Tropical Biomedicine 4: 451-455

Rajamohan A, Rinehart JP, Leopold RA (2014) Cryopreservation of embryos of Lucilia sericata (Diptera: Calliphoridae). Journal of medical entomology 51: 360-367.

Rajamohan A, Rinehart JP, Foster SP, Leopold RA (2013) Permeability barriers to embryo cryopreservation of Pectinophora gossypiella (Lepidoptera: Gelechiidae). Journal of Economic Entomology 106: 855-861.

Rinehart JP, Yocum GD, Kemp WP, Greenlee KJ (2013) A fluctuating thermal regime improves long-term survival of quiescent prepupal Megachile rotundata (Hymenoptera: Megachilidae)." Journal of Economic Entomology 106: 10811088 .

Saeidi F, Moharramipour S, Mikani A (2017) Rapid Cold Hardening Capacity and Its Impact on Performance of Russian Wheat Aphid (Hemiptera: Aphididae). Environmental Entomology 46: 954-959.

Saleh V, Soltani A, Dabaghmanesh T, Alipour H, Azizi K, Moemenbellah-Fard MD (2014) Mass rearing and life table attributes of two cyclorrhaphan flies, Lucilia sericata meigen 
(Diptera: Calliphoridae) and Musca domestica L. (Diptera: Muscidae) under laboratory conditions. Journal of Entomology 11:291-298.

Salt R (1961) Principles of insect cold-hardiness. Annual Review of Entomology 6: 55-74.

Santacruz EN, Venette R, Dieckhoff C, Hoelmer K, Koch RK (2017) Cold tolerance of Trissolcus japonicus and T. cultratus, potential biological control agents of Halyomorpha halys, the brown marmorated stink bug. Biological Control 107: 11-20.

Sheikh AA, Rehman N, Kumar R (2017) Diverse adaptations in insects: A Review. Journal of Entomology and Zoology Studies 5: 343-350.

Sherman RA, Shimoda KJ (2004) Presurgical maggot debridement of soft tissue wounds is associated with decreased rates of postoperative infection. Clinical infectious diseases 39:
1067-1070.

Suszkiw J (2005) Frozen flies safeguard research, screwworm eradication efforts. Agricultural Research 53: 14.

Tourle R, Downie DA, Villent MH (2009) Flies in the ointment: a morphological and molecular comparison of Lucilia cuprina and Lucilia sericata (Diptera: Calliphoridae) in South Africa. Medical and Veterinary Entomology 23: 6-14.

Wang Q, Tanne E, Arav A (2000) Cryopreservation of in vitrogrown shoot tips of grapevine by encapsulation-dehydration. Plant Cell, Tissue and Organ Culture 63: 41-46.

Zajac BK, Amendt J, Verhoff MA, Zehner R (2018) Dating Pupae of the Blow Fly Calliphora vicina Robineau-Desvoidy 1830 (Diptera: Calliphoridae) for Post Mortem Interval-Estimation: Validation of Molecular Age Markers. Genes (Basel) 9 : E153. doi: 10.3390/genes9030153. 